\title{
UTILIZATION OF AN ENZYME COMPLEX IN DIETS CONTAINING COTTONSEED CAKE FOR GROWING PIGS
}

\section{UTILIZAÇÃO DE COMPLEXO ENZIMÁTICO EM DIETAS PARA SUÍNOS EM CRESCIMENTO CONTENDO TORTA DE ALGODÃO}

\author{
Liliane Olímpio Palhares ${ }^{1^{*}}$ ORCID http://orcid.org/0000-0003-0282-9616 \\ Wilson Moreira Dutra Júnior ${ }^{1}$ ORCID http://orcid.org/0000-0002-5624-5942 \\ Débora Nathália Moura Ferreira1 ORCID http://orcid.org/0000-0002-2441-2718 \\ Marconi Italo Lourenço-Silva² ORCID http://orcid.org/0000-0002-3636-4805 \\ Andrew Henrique Silva Cavalcanti Coelho ${ }^{1}$ ORCID http://orcid.org/0000-0001-9139-3249 \\ Izaura Maria Barros de Lorena-Rezende ${ }^{1}$ ORCID http://orcid.org/0000-0001-6233-6018 \\ Maria do Carmo Mohaupt Marques Ludke ${ }^{1}$ ORCID http://orcid.org/0000-0003-4895-2599
}

\author{
${ }^{1}$ Universidade Federal Rural de Pernambuco - Recife, PE, Brazil. \\ 2Universidade Estadual Paulista - Botucatu, SP, Brazil. \\ *Corresponding author - lilianepalhares@zootecnista.com.br
}

\begin{abstract}
Two experiments were conducted with pigs in the growth phase (30-50 kg). Experiment I consisted of a digestibility trial to determine the nutritional value of cottonseed cake with and without addition of an enzyme complex through the method of total collection of excreta. Twenty barrows were used and housed in metabolic cages to collect the total collection of feces and urine. Four treatments and five replications randomized the experimental design completely. Two reference diets and two test diets were experimental ( $70 \%$ reference diet and $30 \%$ cottonseed cake), with and without the addition of an enzyme complex. The evaluated variables were: apparent digestibility coefficient of dry matter, of crude protein, of Gross energy, of phosphorus and the values of digestible dry matter, digestible protein, digestible phosphorus, digestible energy and metabolizable energy of cottonseed cake with and without enzymes. The addition of enzymes increased the levels of digestible protein to $0.302-$ $0.313 \mathrm{~kg} / \mathrm{kg}$ and digestible energy to $2,538-2,894 \mathrm{kcal} / \mathrm{kg}$. Experiment II was conducted to assess barrow performance when they were fed diets containing increasing levels of cottonseed cake protein $(0,20,40$ and $60 \%)$, which replaced protein from soybean meal, with the enzyme complex. The design was a randomized block design consisting of four treatments and five replications. The performance, carcass characteristics and biochemical parameters of the blood were evaluated. These results indicate that the protein from soybean meal can be replaced up to $60 \%$ by the cottonseed cake protein with enzyme complex in diets for pigs in the growth phase, without sacrificing performance or carcass characteristics
\end{abstract}

Keywords: additives, digestibility, food protein, performance, swine

\section{Resumo}

Foram conduzidos dois experimentos com suínos na fase de crescimento (30-50 kg), o experimento I consistiu de um ensaio de digestibilidade, com objetivo de determinar o valor nutricional da torta de algodão com e sem adição de complexo enzimático através do método de coleta total de excretas. Foram utilizados 20 suínos, machos castrados, alojados em gaiolas metabólicas para realização da coleta das fezes e da urina. O delineamento experimental foi inteiramente casualizado, contendo 
quatro tratamentos e cinco repetições. As dietas experimentais foram: ração referência e ração teste (70\% de ração referência e $30 \%$ de torta de algodão), com e sem adição do complexo enzimático. Foram determinados os coeficientes de digestibilidade aparente da matéria seca, da proteína bruta, da energia bruta, e do fósforo. Como também os valores de matéria seca digestível, proteína digestível, fósforo digestível, energia digestível e energia metabolizável da torta de algodão com e sem enzima. A adição das enzimas aumentou os teores de proteína digestível de 30,28 para $31,36 \%$ e energia digestível de 2.538 para $2.894 \mathrm{kcal} / \mathrm{kg}$. No experimento II foi avaliado o desempenho de 20 suínos machos castrados alimentados com níveis crescentes de substituição da proteína do farelo de soja pela proteína da torta de algodão $(0,20,40$ e $60 \%)$ com complexo enzimático.O delineamento foi realizado em blocos casualizados constituído de quatro tratamentos e cinco repetições. Foi avaliado o desempenho, características de carcaça e parâmetros sanguíneos. Os resultados indicam que a proteína do farelo de soja pode ser substituída até $60 \%$ pela proteína da torta de algodão com o complexo enzimático em rações de suínos na fase de crescimento, sem prejudicar o desempenho e características de carcaça.

Palavras-chaves: aditivos, alimento proteico, desempenho, digestibilidade, leitões

Received on December 11 $1^{\text {th }}, 2018$.

Accepted on August $5^{\text {th }} .2019$.

\section{Introduction}

Co-products resulting from the seed of the cotton plant (Gossypium hirsutum L.) after oil extraction represent the third protein source available for animal feed worldwide, in accordance with Ash and $\operatorname{Dohlman}^{(1)}$, and it is considered an excellent alternative to prepare feed for pigs. However, itsapplication in feeding non-ruminants as a single protein supplementation in diets is limited, due to its high crude fiber. Diets with a high concentration of crude fiber increases peristalsis and, consequently, accelerates intestinal transit, decreasing the time of contact with the enzymes responsible for digestion, and the time available for absorption of nutrients ${ }^{(2)}$.

An alternative to fiber degradation of cottonseed cake is the addition of a digestive enzyme complex to the feed. Exogenous enzymes promote the rupture of cell walls, reduce intestinal viscosity caused by non-starch polysaccharides, and suppress the effect of antinutritional properties present in foodstuffs ${ }^{(3)}$. Enzyme supplementation can act as an important tool, efficiently facilitating digestion and increasing the availability of nutrients.

Thus, the working hypothesis is that the addition of the enzyme complex on diets base of cottonseed cake improves the nutrients digestibility, performance and carcass yield for pigs. The objectives of this study were to determine the nutritional value of cottonseed cake with and without an enzyme complex, and to identify the replacement level of soybean meal protein by cottonseed cake protein with the enzymatic complex supplementation in diets for pigs in the growth phase.

\section{Materials and methods}

All procedures used in the present experiment were submitted to the Ethics Committee on the use of Animals of the University Federal Rural of Pernambuco (CEUA-UFRPE) and was approved by 
license $n^{\circ}$ 069/2013. The experiments were conducted at the Swine Sector of the Department of Animal Science at UFRPE.

Cottonseed cake $(\mathrm{CK})$ was obtained by mechanical pressing, after steam heating. The $\mathrm{CK}$ was treated with ferrous sulfate $\left(\mathrm{FeSO}_{4}\right)$ in a 1:1 proportion (iron:free gossypol) before being added to the experimental diets, with the aim of avoiding gossypol effects.

The CK samples used in this experiment were analyzed for dry matter (DM), crude protein (CP), ether extract (EE), calcium and total phosphorus (TP) (Silva and Queiroz, 2005). Gross energy (GE) was determined via bomb calorimeter (IKA $200^{\circledR}$ ), crude fiber (CF) was determined by following the method of Weende ${ }^{(7)}$, and neutral detergent fiber (NDF) and acid detergent fiber (ADF) were determined using the method of Van Soest et al. ${ }^{(8)}$.

Determination of the total amino acid composition of cottonseed cake was analyzed at Company Evonik Industries AG Feed Additives/Animal Nutrition Services, through near-infrared spectroscopy (NIR). The free gossypol (FG) of cottonseed cake was analyzed at Laboratory Labtron ${ }^{\circledR}$ using the methodology described by Pons and Guthrie ${ }^{(9)}$.

The chemical composition of cottonseed cake is shown in Table 1.

Table 1. Analyzed composition of the cottonseed cake (as natural matter)

\begin{tabular}{lc}
\hline Item & Cottonseed cake \\
Chemical and energetic composition & \\
\hline Dry matter $\left(\mathrm{g} \mathrm{kg}^{-1}\right)$ & 903.6 \\
Crude protein $\left(\mathrm{g} \mathrm{kg}^{-1}\right)$ & 222.5 \\
Ether extract $\left(\mathrm{g} \mathrm{kg}^{-1}\right)$ & 90.4 \\
Crude fiber $\left(\mathrm{g} \mathrm{kg}^{-1}\right)$ & 223.0 \\
Neutral detergent fiber $\left(\mathrm{g} \mathrm{kg}^{-1}\right)$ & 437.7 \\
Acid detergent fiber $\left(\mathrm{g} \mathrm{kg}^{-1}\right)$ & 319.5 \\
Calcium $\left(\mathrm{g} \mathrm{kg}^{-1}\right)$ & 2.7 \\
Phosphorus $\left(\mathrm{g} \mathrm{kg}^{-1}\right)$ & 10.2 \\
Gross Energy $\left(\mathrm{kcal}^{-1} \mathrm{~kg}^{-2}\right)$ & 4,396 \\
Free gossypol $\left(\mathrm{mg}^{-1} \mathrm{~kg}^{2}\right)$ & 977 \\
Amino acid composition $\left(\mathrm{g} \mathrm{kg}^{-1}\right)$ & \\
Arginine & 32.5 \\
Lysine & 11.7 \\
Methionine & 3.9 \\
Methionine+Cystine & 8.5 \\
Threonine & 8.7 \\
Tryptophan & 3.6 \\
Valine & 12.2 \\
\hline
\end{tabular}

The enzyme complex was provided by the company Bioenzima and comprised cellulose (15.53 U/g), endoglucanase $(27.35 \mathrm{U} / \mathrm{g})$, xylanase $(77.47 \mathrm{U} / \mathrm{g})$, pectinase $\left(1,26 \times 10^{3} \mathrm{U} / \mathrm{g}\right)$, $\beta$-glucanase $\left(5.17 \times 10^{2} \mathrm{U} / \mathrm{g}\right)$, protease $\left(2.95 \times 10^{2} \mathrm{U} / \mathrm{g}\right)$ and phytase $(2.06 \mathrm{U} / \mathrm{g})$; each unit of enzyme activity released1 $\mu \mathrm{mol}$ of nutrient per gram per minute $\left(U=\mathrm{min}^{-1}\right)$ and added $300 \mathrm{mg}$ for each kilo of feed. 


\section{Experiment I - Digestibility}

Twenty growing crossbred barrows [(Large White $\mathrm{x}$ Duroc) $\mathrm{x}$ Landrace] with an initial body weight of $29.3 \pm 2.81 \mathrm{~kg}$ were used to assess digestibility. The animals were housed individually in stainless steel metabolism cages, as described by Pekas ${ }^{(4)}$, under anenvironmental temperature of $26.5 \pm 2.27{ }^{\circ} \mathrm{C}$ (minimum) and $33.51 \pm 1.07{ }^{\circ} \mathrm{C}$ (maximum), and relative humidity between $33.21 \pm 2.20 \%$ (minimum) and $68.0 \pm 9.55 \%$ (maximum). The experimental design was completely randomized, with four treatments and five replications, consisting of one pig per pen.

Treatments consisted of a reference diet (based on corn and soybean meal); a reference diet (based on corn and soybean meal) with theenzyme complex; a test diet (70\% reference diet and $30 \%$ of cottonseed cake); and a test diet (70\% reference diet and 30\% of cottonseed cake) with theenzyme complex. The reference diet was formulated to meet or exceed Brazilian Tables for Poultry and Swine $^{(5)}$ (Table 2).

Table 2. Composition of the experimental diet (\%, as-fed basis)

\begin{tabular}{lc}
\hline Ingredient & Reference diet \\
\hline Corn & 71.63 \\
Soybean meal & 24.86 \\
Dicalcium phosphate & 1.15 \\
Limestone & 0.71 \\
Soybean oil & 0.48 \\
Common salt & 0.40 \\
Vitamin and mineral supplement $(1)$ & 0.40 \\
L-Lysine HCl & 0.25 \\
DL-Methionine & 0.06 \\
L-Threonine & 0.06 \\
\hline TOTAL & 100.00
\end{tabular}

\begin{tabular}{lc}
\hline \multicolumn{2}{c}{ Composition Calculated, \% } \\
\hline Crude protein & 17.2 \\
Lysine dig. & 0.95 \\
Methionine dig. & 0.29 \\
Threonine dig. & 0.62 \\
Thyptophan dig. & 0,17 \\
Calcium & 0.63 \\
Available phosphorus & 0.31 \\
Metabolizable energy $(\mathrm{kcal} / \mathrm{kg})$ & 3,230 \\
\hline
\end{tabular}

(1) Amount per kg/diet: Folic acid $250 \mathrm{mg}$; Biotin $7.5 \mathrm{mg}$; Choline chloride $40 \mathrm{~g} / \mathrm{kg}$; Vit. A 1,000 UI; Vit.B12 4,500 mg; Vit. D3 150,000 UI; Vit. E 3,000 UI; Vit. K $750 \mathrm{mg}$; Vit. B1 $150 \mathrm{mg}$; Vit. B2 $875 \mathrm{mg}$; Vit. B6: $250 \mathrm{mg}$; Copper 3,750 mg; Iron $8,750 \mathrm{mg}$; Iodine $250 \mathrm{mg}$; Manganese $88,250 \mathrm{mg}$; Niacin 5,000 $\mathrm{mg}$; Calciumpantothenate 2,500 mg; Selenium $75 \mathrm{mg}$; Zinc $18.75 \mathrm{~g}$.

The evaluation of digestibility was performed by the method of total collection (feces and urine), for a trial period of ten days: five days were the adaptation phase and the other five days were collection. 
The daily feed was defined through the metabolic weight $\left(\mathrm{BW}^{0,75}\right)$ of each pig. It was provided in two equal parts, which were given at 08:00 and 16:00 h. Water was available ad libitum through a drinking nipple. The collection and sample preparation of feces and urine were conducted as per the method described by Sakomura and Rostagno ${ }^{(6)}$. The samples were defrosted, homogenized for each animal and aliquots were taken. Feces samples were pre-dried in an oven with forced air ventilation at $55^{\circ} \mathrm{C}$ for 72 hours, withsubsequent milling using a knife mill with a $1 \mathrm{~mm}$ sieve and was collected for chemical analysis.

The samples used in this experiment were analyzed for dry matter (DM), crude protein (CP), ether extract (EE), calcium and total phosphorus (TP) (Silva and Queiroz, 2005). Gross energy (GE) was determined via bomb calorimeter (IKA $200^{\circledR}$ ), crude fiber (CF) was determined following the method of Weende ${ }^{(7)}$, and neutral detergent fiber (NDF) and acid detergent fiber (ADF) were determined using the method of Van Soest et al. ${ }^{(8)}$.

Apparent digestibility coefficients were calculated for dry matter (ADCDM), crude protein (ADCCP), crude fiber (ADCCD), neutral detergent fiber (ADCNDF), gross energy (ADCGE), total phosphorus (ADCTP), and values of digestible dry matter (DDM), digestible protein (DP), digestible fiber (DF), digestible neutral detergent fiber (DNDF), digestible phosphorus (DPh), digestible energy (DE) and metabolizable energy (ME) of cottonseed cake, using the formulas described by Matterson et al. ${ }^{(10)}$. Diets with the enzyme complex were used for calculating the composition of cottonseed cake with the enzyme complex.

All the evaluated variables were subjected to analysis of variance and comparison of means by the $t$ test at the 5\% probability level, using the statistical program Statistics Analysis System version 9.0 ${ }^{(11)}$, according to the following mathematical model:

$$
\mathrm{Y}_{\mathrm{ji}}=\mu+\mathrm{ti}+\mathrm{e}_{\mathrm{ji}},
$$

in which Yij = dependent variables related to Apparent digestibility coefficients of animals receiving treatment $\mathrm{i}$ (cottonseed cake without enzyme and cottonseed cake with enzyme) in replicate $\mathrm{j}(1,2$, 3 , or 4); $\mu$ = overall mean of the variable; $\mathrm{ti}=$ effect of treatment I (cottonseed cake without enzyme and cottonseed cake with enzyme); and eij = random error associated with each observation.

\section{Experiment II - Performance trial}

Twenty growing crossbred barrows [(Large White $\mathrm{x}$ Duroc) $\mathrm{x}$ Landrace] with initial body weight (BW) of $27.84 \pm 2.96 \mathrm{~kg}$ were used to assess performance. The animals were individually housed in $1.20 \times 3.10 \mathrm{~m}^{2}$ pens with concrete floors. Each pen was equipped with a stainless-steel feeder and a nipple drinker. The environmental temperature was registered as $25.04 \pm 2.09{ }^{\circ} \mathrm{C}$ (minimum) and $30.19 \pm 1.21^{\circ} \mathrm{C}$ (maximum), and relative humidity was registered at $36.05 \pm 4.09 \%$ (minimum) and $69.94 \pm 14.23 \%$ (maximum). The experimental design was assigned a randomized complete block, with four treatments and five replications. Pigs were blocked on the basis of BW.

Treatments consisted of the following diets: CDE - control diet, based on corn and soybean meal; D20CKE - CDE with replacement of $20 \%$ protein from soybean meal by the cottonseed cake protein; D40CKE - CDE with replacement of $40 \%$ protein from soybean meal by the cottonseed cake protein; D60CKE - CDE with replacement of $60 \%$ protein from soybean meal by the cottonseed cake protein. Protein value supplied by cottonseed cake replaced in $20 \% 40 \%$ and $60 \%$ the protein value provided by soybean meal in the diets.All diets contained the enzyme complex. 
All the diets were formulated to meet the nutritional requirements of animals according to Brazilian Tables for Poultry and Swine ${ }^{(5)}$ (Table 3), except for metabolizable energy, crude protein and available phosphorus, which were reduced by $1.5 \%$, for the addition of the enzyme complex, aiming that the enzymes to release the nutrients retained by the non-starch polysaccharides.

Table 3. Composition of the experimental diets (\%, as-fed basis)

\begin{tabular}{|c|c|c|c|c|}
\hline \multirow{2}{*}{ Ingredients } & \multicolumn{4}{|c|}{ Treatments } \\
\hline & CDE & CK20E & CK40E & CK60E \\
\hline Corn & 73.390 & 65.940 & 58.400 & 50.850 \\
\hline Soybean meal & 23.060 & 19.720 & 16.300 & 12.880 \\
\hline Cottonseed cake & - & 9.330 & 18.660 & 27.990 \\
\hline Inert & 0.500 & 0.500 & 0.500 & 0.500 \\
\hline Soybean oil & - & 1.495 & 3.059 & 4.623 \\
\hline Dicalcium phosphate & 1.100 & 1.168 & 1.236 & 1.303 \\
\hline Limestone & 0.680 & 0.603 & 0.526 & 0.450 \\
\hline Common salt & 0.410 & 0.370 & 0.382 & 0.393 \\
\hline $\begin{array}{l}\text { Vitamin and mineral supplement } \\
\text { (1) }\end{array}$ & 0.400 & 0.400 & 0.400 & 0.400 \\
\hline L-Lysine $\mathrm{HCl}$ & 0.277 & 0.318 & 0.363 & 0.408 \\
\hline DL-Methionine & 0.025 & 0.032 & 0.039 & 0.046 \\
\hline L-Threonine & 0.121 & 0.084 & 0.100 & 0.116 \\
\hline L-Tryptophan & - & 0.002 & 0.006 & 0.010 \\
\hline Enzyme complex & 0.030 & 0.030 & 0.030 & 0.030 \\
\hline TOTAL & 100 & 100 & 100 & 100 \\
\hline \multicolumn{5}{|l|}{ Values Analyzed } \\
\hline Crude protein (\%) & 16.21 & 16.24 & 16.23 & 16.28 \\
\hline Total phosphorus (\%) & 0.56 & 0.78 & 0.78 & 0.71 \\
\hline Neutral detergent fiber $(\%)$ & 12.01 & 17.68 & 18.24 & 19.47 \\
\hline Crude fiber (\%) & 2.37 & 4.01 & 5.89 & 6.87 \\
\hline Gross energy (kcal/kg) & 4,003 & 4,072 & 4,116 & 4,322 \\
\hline Free gossypol $(\mathrm{mg} / \mathrm{kg})^{(2)}$ & - & 91.15 & 182.31 & 273.46 \\
\hline \multicolumn{5}{|l|}{ Composition Calculated } \\
\hline Crude protein $(\%)$ & 16.57 & 16.57 & 16.57 & 16.57 \\
\hline Lysine dig. (\%) & 0.927 & 0.927 & 0.927 & 0.927 \\
\hline Methionine dig. (\%) & 0.278 & 0.278 & 0.278 & 0.278 \\
\hline Threonine dig. (\%) & 0.603 & 0.603 & 0.603 & 0.603 \\
\hline Tryptophan dig. (\%) & 0.167 & 0,167 & 0.167 & 0.167 \\
\hline Calcium (\%) & 0.63 & 0.63 & 0.63 & 0.63 \\
\hline Available phosphorus (\%) & 0.306 & 0.306 & 0.306 & 0.306 \\
\hline Metabolizable energy $(\mathrm{kcal} / \mathrm{kg})$ & 3,181 & 3,181 & 3,181 & 3,181 \\
\hline
\end{tabular}

(1) Amount per kg/diet: Choline: 37.5 g; Vit. A: 1,625,000 UI; Vit. D3: 400,000 UI; Vit. E: 7,500UI; Vit. K3: $750 \mathrm{mg}$; Vit. B1: $550 \mathrm{mg}$; Vit. B2: $1.375 \mathrm{mg}$; Vit. B6: $500 \mathrm{mg}$; Vit. B12: $5.000 \mathrm{mg}$; Niacin: $5.000 \mathrm{mg}$; Acidpantothenate: $2.300 \mathrm{mg}$; Folicacid: $125 \mathrm{mg}$; Biotin: $7,5 \mathrm{mg}$; Ferro: $25 \mathrm{~g}$; Copper: 3.750 mg; Manganese: $12,5 \mathrm{~g}$; Zinc: 31,25 g; Iodine: $250 \mathrm{mg}$; Selenium: $75 \mathrm{mg}$. (2) Value estimated by cottonseed cake analyze 
Performance lasted 35 days:7 days to adapt to feed and 28 days to assess the animals' performance. The animals had free access to drinking water and feed. Feed intake was recorded in order to determine average daily feed intake (ADFI). Body weight was measured at the beginning and end of the experiment in order to average body daily gain (ABDG) to compute the feed conversion ratio (FCR).

Carcass measurements were performed in vivo by ultrasound in the beginning and end of the experiment, using the ultrasound machine Pie Medical Model Aquila ${ }^{\circledR}$. It measured the loin eye area (LEA), backfat thickness (BT) and depth of muscle (DM), following the method described by Dutra Jr. et al. ${ }^{(12)}$.

Blood samples were collected in all the animals at the end of the experiment from the orbital sinus of animals using hypodermic needles $(40 \times 1.6 \mathrm{~mm})$. These were stored in $10 \mathrm{~mL}$ tubes without anticoagulant to obtain serum and $5 \mathrm{~mL}$ tubes with sodium fluoride and ethylenediaminetetraacetic acid (EDTA) to obtain plasma. Tubes with samples were centrifuged in 3,000 rpm, for 10 minutes, separating the serum and plasma. This was transferred to a microcentrifuge tube with identification. Serum samples were submitted to the following analyses: total protein, urea, uric acid, creatinine and phosphorus. The plasma sample was analyzed for glucose. All samples were analyzed using a SemiAutomatic Biochemistry Analyzer (Doles D250 ${ }^{\circledR}$ ) and commercial kits, according to the manufacturer's instructions.

Data were subjected to analysis of variance by applying the PROC GLM procedure of Statistics Analysis System version 9.0 $0^{(1)}$, according to the following mathematical model:

$$
Y i j=\mu+t i+e i j,
$$

in which Yij = dependent variables related to performance, digestibility, and blood parameters of animals receiving treatment $\mathrm{i}$ (cottonseed cake level: CDE, CK20E, CK40E or CK60E) in replicate j $(1,2,3,4$ or 5$) ; \mu=$ overall mean of the variable; $t i=$ effect of cottonseed cake level $\mathrm{i}$; and eij $=$ random error associated with each observation.

Regression analyses subjected variables for which significant effects were detected as a function of cottonseed cake, adopting a 5\% probability level. The PROC REG statistical package of Statistics Analysis System version $9.0^{(11)}$ was applied to obtain the regression equations and thus estimate the cottonseed cake level. The variables referring to carcass characteristics were submitted to analysis of variance and repeated measure, using the data of 20 barrows assessed at two different times (initial and final).

\section{Results}

\section{Experiment I}

The addition of the enzyme complex affected digestibility coefficient for crude protein and digestible protein values of cottonseed cake $(\mathrm{p}<0.05)$ (Table 4$)$. The highest values were recorded in CK with addition of complex enzymatic, and the same occurred with digestible neutral detergent fiber and digestible energy $(\mathrm{p}<0.03)$. The addition of the enzyme complex did not affect metabolizable energy, though it did provide an increase of approximately $250 \mathrm{kcal} / \mathrm{kg}$ with the addition of enzymes. 
Table 4. Apparent digestibility coefficient, values of digestible and metabolizable of nutrients and energy of cottonseed cake with or without enzyme complex

\begin{tabular}{|c|c|c|c|c|c|}
\hline \multirow{2}{*}{ Parameters } & \multicolumn{3}{|c|}{ Cottonseed cake (CK) } & \multirow[b]{2}{*}{$\mathbf{P}$} & \multirow[b]{2}{*}{ CV (\%) } \\
\hline & Without Enzyme & With enzyme & Average & & \\
\hline $\operatorname{ADCDM}\left(\mathrm{kg} \mathrm{kg}^{-1}\right)$ & 0.429 & 0.475 & 0.452 & 0.14 & 8.18 \\
\hline $\operatorname{ADCCP}\left(\mathrm{kg} \mathrm{kg}^{-1}\right)$ & $0.763 b$ & $0.806 \mathrm{a}$ & 0.784 & 0.04 & 3.53 \\
\hline $\mathrm{ADCCF}\left(\mathrm{kg} \mathrm{kg}^{-1}\right)$ & 0.238 & 0.236 & 0.237 & 0.13 & 5.54 \\
\hline $\mathrm{ADCNDF}\left(\mathrm{kg} \mathrm{kg}^{-1}\right)$ & 0.274 & 0.284 & 0.279 & 0.11 & 19.1 \\
\hline $\operatorname{ADCGE}\left(\mathrm{kg} \mathrm{kg}^{-1}\right)$ & 0.484 & 0.539 & 0.512 & 0.12 & 9.56 \\
\hline $\operatorname{ADCTP}\left(\mathrm{kg} \mathrm{kg}^{-1}\right)$ & 0.330 & 0.355 & 0.370 & 0.31 & 39.21 \\
\hline \multicolumn{6}{|c|}{ Values digestible and metabolizable } \\
\hline $\mathrm{DDM}\left(\mathrm{kg} \mathrm{kg}^{-1}\right)$ & 0.429 & 0.478 & 0.453 & 0.13 & 8.30 \\
\hline $\mathrm{DP}\left(\mathrm{kg} \mathrm{kg}^{-1}\right)$ & $0.302 b$ & $0.313 \mathrm{a}$ & 0.308 & 0.03 & 2.19 \\
\hline $\mathrm{DF}\left(\mathrm{kg} \mathrm{kg}^{-1}\right)$ & 0.011 & 0.010 & 0.010 & 0.12 & 12.5 \\
\hline $\operatorname{DNDF}\left(\mathrm{kg} \mathrm{kg}^{-1}\right)$ & $0.137 \mathrm{~b}$ & $0.170 \mathrm{a}$ & 0.153 & 0.02 & 8.10 \\
\hline $\mathrm{DPh}\left(\mathrm{kg} \mathrm{kg}^{-1}\right)$ & 0.0030 & 0.0036 & 0.0033 & 0.91 & 48.0 \\
\hline $\mathrm{DE}(\mathrm{Kcal} / \mathrm{kg})$ & $2,538.41 b$ & $2,894.27 \mathrm{a}$ & $2,716.34$ & 0.02 & 7.48 \\
\hline $\mathrm{ME}(\mathrm{Kcal} / \mathrm{kg})$ & $2,443.17$ & $2,690.26$ & $2,566.72$ & 0.16 & 10.5 \\
\hline
\end{tabular}

P probability, CV coefficient of variation, ADCDM apparent digestibility coefficient dry matter, ADCCP apparent digestibility coefficient crude protein, ADCCF apparent digestibility coefficient crude fiber, ADCNDF apparent digestibility coefficient neutral detergent fiber, ADCTP apparent digestibility coefficient total phosphorus, ADCGE apparent digestibility coefficient gross energy, DDM digestible dry matter, DP digestible protein, DF digestible fiber, DNDF digestible neutral detergent fiber, $\mathrm{DPh}$ digestible phosphorus, DE digestible energy and ME metabolizable energy

\section{Experiment II}

The increasing levels of replacement protein from soybean meal by the cottonseed cake did not affect the general performance or carcass characteristics of the animals ( $p>0.05)$ (Table 5).

Table 5. Effects of dietary with levels of cottonseed cake and enzyme complex on performance and carcass charters in growth pigs

\begin{tabular}{|c|c|c|c|c|c|c|c|}
\hline \multirow{2}{*}{ Parameters } & \multicolumn{4}{|c|}{ Treatments } & \multirow{2}{*}{ Average } & \multirow{2}{*}{ e $\quad C V \%$} & \multirow{2}{*}{$\mathbf{P}$} \\
\hline & CDE & D20CKE & D40CKE & D60CKE & & & \\
\hline FW (kg) & 56.82 & 57.30 & 57.74 & 53.60 & 56.36 & 11.75 & 0.49 \\
\hline ADFI (kg) & 2.28 & 2.22 & 2.32 & 2.03 & 2.21 & 10.28 & 0.27 \\
\hline $\operatorname{ABDG}(\mathrm{kg})$ & 1.02 & 1.05 & 1.07 & 0.93 & 1.02 & 13.06 & 0.39 \\
\hline FCR & 2.23 & 2.12 & 2.13 & 2.16 & 2.16 & 6.99 & 0.64 \\
\hline \multirow{2}{*}{\multicolumn{5}{|c|}{ Carcass characters }} & \multicolumn{3}{|c|}{ Probability } \\
\hline & & & & & Treat. $\mathrm{T}$ & Time & Treat. X Time \\
\hline $\operatorname{LEA}_{\mathrm{I}}\left(\mathrm{cm}^{2}\right)$ & 13.94 & 13.74 & 13.29 & 12.72 & \multirow{2}{*}{0.42} & \multirow{2}{*}{$<0.001$} & \multirow{2}{*}{0.87} \\
\hline $\operatorname{LEAF}\left(\mathrm{cm}^{2}\right)$ & 25.07 & 23.66 & 24.21 & 21.90 & & & \\
\hline $\mathrm{BT}_{\mathrm{I}}(\mathrm{cm})$ & 0.39 & 0.36 & 0.35 & 0.33 & \multirow{2}{*}{0.69} & \multirow{2}{*}{$<0.001$} & \multirow{2}{*}{0.56} \\
\hline $\mathrm{BT}_{\mathrm{F}}(\mathrm{cm})$ & 0.58 & 0.60 & 0.65 & 0.57 & & & \\
\hline $\mathrm{DMI}_{\mathrm{I}}(\mathrm{cm})$ & 2.16 & 2.16 & 2.31 & 2.20 & \multirow{2}{*}{0.68} & \multirow{2}{*}{$<0.001$} & \multirow{2}{*}{0.93} \\
\hline $\mathrm{DMF}_{\mathrm{F}}(\mathrm{cm})$ & 3.24 & 3.23 & 3.34 & 3.10 & & & \\
\hline
\end{tabular}


The total serum protein of the pigs showed a linear reduction, by approximately $10 \%$, with increasing levels of $\mathrm{CK}$ in the feed $(\mathrm{p}<0.001)$. However, the glucose, phosphorus, urea, uric acid and creatinine levels werenot affected by treatments.

Table 6. Effects of dietary with levels of cottonseed cake and enzyme complex on the biochemical parameters serum in growth pigs

\begin{tabular}{lccccccc}
\hline \multirow{2}{*}{ Parameters } & \multicolumn{9}{c}{ Treatments } & \multirow{2}{*}{ Average } & CV\% & P \\
\cline { 2 - 7 } & CDE & D20CKE & D40CKE & D60CKE & & & \\
\hline Glucose & 91.86 & 108.16 & 98.81 & 91.78 & 96.85 & 17.23 & 0.78 \\
Total protein (1) & 6.15 & 5.83 & 5.83 & 5.55 & 5.81 & 5.84 & 0.01 \\
Phosphorus & 5.93 & 7.01 & 5.28 & 4.81 & 5.55 & 32.56 & 0.19 \\
Urea & 14.98 & 13.29 & 16.63 & 13.63 & 14.67 & 28.18 & 0.13 \\
Creatinine & 0.67 & 0.75 & 0.70 & 0.69 & 0.70 & 15.62 & 0.97 \\
Uric acid & 0.31 & 0.30 & 0.30 & 0.30 & 0.31 & 6.35 & 0.46 \\
\hline
\end{tabular}

(1) $\mathrm{Y}=6.08-0.009 \mathrm{X}, \mathrm{R}^{2}=0.89$

$\mathrm{P}$ probability and $\mathrm{CV}$ coefficient of variation.

\section{Discussion}

\section{Experiment I}

The higher apparent digestibility coefficient crude protein and digestible protein values suggest that the presence of the enzymatic complex could improve the availability of nitrogen from CK, increasing the use of low availability protein or combining with antinutritional factors. The increase of free nitrogen may have occurred through no-starch polysaccharide (NSP) hydrolysis. No-starch polysaccharide acts as a physical barrier to the digestion and absorption of nutrients, due to increase intestinal viscosity ${ }^{(13)}$.

The increase of approximately $24 \%$ digestible neutral detergent fiber emphasizes the enzymatic complex performance on NSP hydrolysis, extending the enzyme action to fractions of less available food, increasing digestibility and causing more free monosaccharides, because the enzyme complex used was mostly compounds of carbohydrase. This explains the increase of digestible energy with the addition of the enzyme complex, showing that the enzyme complex may provide higher digestible energy, through making use of the fiber contained in the food.

\section{Experiment II}

According to the performance and carcass characteristic results for growing pigs, replacing protein from soybean meal with cottonseed cake protein by up to $60 \%$, with the enzyme complex addition, can be done without sacrificing the performance and carcass characteristics. In this research, the maximum inclusion of the cottonseed cake in the diets was $27.99 \%$. However, a different response was found by FombadandBryant ${ }^{(14)}$, who recommended that the maximum level of CK for inclusion in pig feed was $15 \%$ (but without enzymes). This demonstrates the utilization efficiency of the enzyme complex in pig diets when the food contains a high level of fiber. 
The linear decrease $(\mathrm{P}<0.05)$ in serum total protein according to cottonseed cake levels added to the diets could be associated with the presence of gossypol and the low composition of lysine and tryptophan on cottonseed cake.

The cottonseed cake is an excellent protein source for pigs, although there is an anti-nutritional factor, gossypol $\left(\mathrm{C}_{30} \mathrm{H}_{30} \mathrm{O}_{8}\right)$, a toxic polyphenolic compound, which acts as an inhibitor of enzymes activity causing the nutritional reduction of the cottonseed cake ${ }^{(15)}$.

During the cottonseed oil extraction, the gossypol readily binds with amino acids constituents of the cotton protein, especially to the amino group of lysine and thereby reducing proteolytic action ${ }^{(16)}$.

Gossypol binds to lysine, resulting in a complex form that non-toxic to animals, the gastrointestinal tract does not absorb this complex, but this causes decrease lysine availability and protein digestibility ${ }^{(17)}$.

The reduction of $1.5 \%$ of crude protein in the diets should also have intensified this result; aiming to replace the nutritional value of the standard diet through the enzyme complex addition it was performed the reduction of nutrients whereas in balanced diet the enzymes cannot show its effectiveness.

When growing pigs are well fed, they show a total serum protein concentration of $7.9-8.0 \mathrm{~g} / \mathrm{dL}^{(18)}$. It can be observed that all the animals were below the normal concentration, and this indicates that the protease activity from the enzymatic complex was not very efficient to replace the decreased $1.5 \%$ requirement of the diets. However, the total serum protein decrease did not influence the animals' performance. Decreasing protein in diets for pigs in the growth phase can result in a delay in body development and low muscle deposition, although, as the LEA was not reduced. Glucose levels were not influenced by diets and were within the normal concentrations of 85 to $150 \mathrm{mg} / \mathrm{dL}$ for swine ${ }^{(18)}$, demonstrating the enzyme complex efficiency on the release of glucose, despite the reduction of $1.5 \%$ ME of the diets.

\section{Conclusions}

In general, the enzyme complex rather increases the digestible protein, neutral detergent fiber, and energy of the cottonseed cake during the grower phase of pigs.

The diet, containing replacement level of soybean meal protein by cottonseed cake protein at the level of $60 \%$ with the enzymatic complex supplementation, did not affect performance and carcass characteristics of pigs in the growth phase.

\section{Acknowledgements}

The authors would like to thank the Instituto Nacional de Ciência e Tecnologia de Ciência Animal (INCT-CA), CNPq and Bioenzima for financial resources.

\section{References}

1. Ash M, Dohlman E. Oil crops situation and outlook yearbook. Electronic outlook report from the economic 
research service. U. S. DepartmentofAgriculture, 2006.

2. Kerr BJ, Shurson GC Strategies to improve fiber utilization in swine. Journal Animal Science Biotechnology, 2013; 4 (1), 11.

3. Neill HVMO, Smith JA, Bedford MR. Multicarbohydrase enzymes for non-ruminants. Asian-Australasian Journal Animal Science. 2014; 27 (2), 290-301.

4. Pekas JC. Versatile swine laboratory apparatus for physiologic and metabolic studies.Journal of Animal Science, Champaing, 1968; 27 (5), 1303-1306.

5. Rostagno HS, Albino LFT, Donzele JL, Gomes PC, Oliveira RF, Lopes DC, Ferreira AS, Barreto SLT, Euclides RF. Brazilian tables for poutry and swine. Universidade Federal de Viçosa, Minas Gerais, BR, 2011, $251 \mathrm{p}$.

6. Sakomura NK, Rostagno HS. Métodos para avaliação biológica dos alimentos e exigências nutricionais para animais monogástricos. Jaboticabal, SP, UNESP. 2007,260p. Portuguese.

7. Silva DJ, Queiroz AC. Análise de alimentos: Métodos químicos e biológicos.3. ed. Viçosa. Universidade Federal de Viçosa., 2005; 235p. Portuguese.

8. Van Soest PJ, Robertson JB, Lewis BA. Methods for dietary fiber, neutral detergent fiber and nonstarch polysaccharides in relation to animal nutrition.Journal of Dairy Science. Savoy, 1991; 74, 3583-3597.

9. Pons WA, Thurber FH, Hoffpauir GL. Prepress-solvent extraction of cottonseed, processing conditions and characteristics of products. Journal of the American Oil Chemistry Society. 1955; 32, 98-103.

10. Matterson LD, Potter L M, Stutz NW. The metabolizable energy of feed ingredients for chickens. Agriculture Experiment Station Research Report, 1965; 65 (7), 3-11.

11. SAS INSTITUTE. System for windows, release 6.12. Cary: 2004. CD-ROM.

12. Dutra JR WM, Ferreira AS, Tarouco JU, Donzele JL, Euclydes RF, Albino LFT, Cardoso LL, Fernandes SP. Predição de características de carcaça de suínos pela técnica de ultra-sonografia em tempo real. RevistaBrasileira de Zootecnia, 2001; 30 (4), 1251 - 1257. Portuguese.

13. Zang L, Xu J, Lei L, Jiang Y, Gao F, Zhou GH. Effects of xylanase supplementation on growth performance, nutrient digestibility and non-starch polysaccharide degradation in different sections of the gastrointestinal tract of broilers fed wheat-based diets. Asian-Australasian Journal Animal Science. 2014.; 27 (6), 855-861.

14. Fombad RB, Bryant MJ. An evaluation of the use of cottonseed cake in the diet of growing pigs. Tropical Animal Health and Production, 2004; 36, 295-305.

15. Gadelha ICN, Rangel AHN, Silva AR, Soto-Blanco B. Efeito do gossipol na reprodução animal. Acta Veterinária, 2011; 5, 129-135.

16.Thirumalaisamy G, Purushothaman MR, Kumar PV, Selvaraj P. Effect of feeding cottonseed meal on some hematological and serum biochemical parameters in broiler bird. Veterinary World, 2016; 9, 723-727.

17. Gadelha IC, Fonseca NBS, Oloris SCS, Melo MM, Soto-Blanco B. Gossypol toxicity from cottonseed products. The Scientific World Journal, 2014, 1, 1-11.

18. Kaneko JJ, Harvey JW, Bruss ML. Clinical biochemistry of domestic animals.6. ed. New York, Academic Press, 2008; 932p. 